Article

\title{
Environmental and Economic Sustainability Assessment for Two Different Sprinkler and A Drip Irrigation Systems: A Case Study on Maize Cropping
}

\author{
Eros Borsato $^{1, *(\mathbb{D})}$, Marco Martello ${ }^{2}$, Francesco Marinello ${ }^{2} \mathbb{D}$ and Lucia Bortolini ${ }^{2}$ (D) \\ 1 Land Environment Resources and Health (LERH) PhD Programme, Territorio e Sistemi \\ Agro-Forestali (TESAF) Department, Università degli studi di Padova, Viale dell'Università 16, \\ 35020 Legnaro, Italy \\ 2 Territorio e Sistemi Agro-Forestali (TESAF) Department, Università degli studi di Padova, Viale \\ dell'Università 16, 35020 Legnaro, Italy \\ * Correspondence: eros.borsato@phd.unipd.it; Tel.: +39-049-8922700
}

Received: 25 July 2019; Accepted: 26 August 2019; Published: 29 August 2019

\begin{abstract}
Water scarcity is worsened by climate change. Water savings can be reached by improving irrigation efficiency both on farm and on water supply. To do that, the choice of the best irrigation technology is not always straightforward, because farmers need to renew and implement farm infrastructures for irrigation. This study compares three irrigation systems, one drip irrigation and two sprinkler (center pivot and hose-reel) systems, on environmental, economic, and energetic performance under irrigated and non-irrigated maize cropping. The study combines impact and efficiency indicators, addressing a sustainability analysis for the irrigation practice under the three different irrigation systems. The sustainability for the irrigation systems was assessed using water-related indicators (water use efficiency, irrigation water use efficiency, and water footprint), biomass (crop growth rate, relative growth rate, harvest index, and yield response factor), and energy indicators (energy footprint, performance, and energy cost footprint) for the environmental aspect; and the economic-based indicators (water productivity and economic water footprint) for the economic aspect. Main results address the center pivot system as the best solution for irrigation practice since it demonstrated higher economic and environmental performance. Moreover, maize under the pivot system allowed a higher biomass production, economic benefits, and water use efficiency.
\end{abstract}

Keywords: efficiency; footprint; indicators; hose-reel; center pivot; water consumption

\section{Introduction}

The agricultural sector uses $70 \%$ of the global freshwater resource [1]. Although only $20 \%$ of global croplands is equipped for irrigation, $40 \%$ of global food production is attributable to irrigated lands [2]. Actually, 24\% of the world river basin area suffers from severe water scarcity [3], and irrigation water use is in conflict with the ecological flows [4] in 15\% of the global lands [5]. The economic welfare of a country is also linked with water depletion; in fact, water poverty increases following an increase of ecosystem degradation [6]. The use of irrigation water enhances crop production, which is usually correlated to higher economic benefits [6]. Hence, sustainable irrigation practice is a strategic enhancement to raise food production and enable the Earth system to operate within planetary boundaries [1,7]. A common opinion for increasing sustainability is given from the implementation of water saving irrigation technologies [8]. Although an increase of irrigation efficiency at the farm scale reduces water consumption at the farm scale, it fails to increase water availability at the watershed and basin scale [9], leading to the irrigation paradox exactly because of an increase of local beneficial water consumption due to a more efficient irrigation system. Moreover, previous non-consumed water 
losses at the farm scale are recovered and reused at the basin scale, and even more, the increase of irrigation efficiency at the farm scale might also increase the water consumption once the farm switches to more water-intense crops [10]. Therefore, sustainable implications of water use refer to integrated environmental preconditions while satisfying the societal demand [11]. In other words, a sort of "semi-sustainability" criterion needs to combine the best possible approach taken by human needs against the resulting environmental depletion [11]. In addition, the human interaction with the water cycle makes some unavoidable changes on water resources [11,12]. For that reason, decision-makers must make better decisions using appropriate tools to support policies and investments $[13,14]$. Thus, the sustainability of irrigation practice could be improved by governance with appropriate water policies [15]. Water policies enhance, for example, the use of water price and subsides to improve sustainable use of water resource [16,17]. As defined for the 6.4 Sustainable Development Goals target, water use indicators should analyze the inter-annual and intra-annual variability of water stress [18], and analyze changes in water management, integrating the several aspects of sustainability $[19,20]$. In fact, a core of indicators better analyze the overall sustainability [21,22]. Especially, the relation among biomass production, the economic productivity related to irrigation water, energy costs, and emissions on the environment permit one to fully understand the sustainability of water use [23,24], and was used in this case study to compare the different irrigation practices.

This study determines the agro-environmental and economic sustainability for supposed suitable irrigation systems, comparing two sprinkler irrigation (center pivot and hose-reel) systems and one drip irrigation system under maize cropping. This study focuses on different irrigation management, comparing irrigation systems and a non-irrigated test using several water-based indicators, analyzing the production of the biomass and yield and looking into their economic and energetic performance.

\section{Materials and Methods}

\subsection{Study Area and Field Management}

This study compared the management of three-irrigation systems during the maize cropping season. The study area was located in the high plain on the northeast of Italy $\left(45^{\circ} 49^{\prime} 44.6^{\prime \prime} \mathrm{N}\right.$; $12^{\circ} 16^{\prime} 35.6^{\prime \prime}$ E) (Figure 1) in proximity to rivers, the mountain area, and the coast. The area is characterized by a sub-continental climate with $1100 \mathrm{~mm}$ of annual rainfall, while during summer season, the area is characterized by warm temperatures and a high humidity.

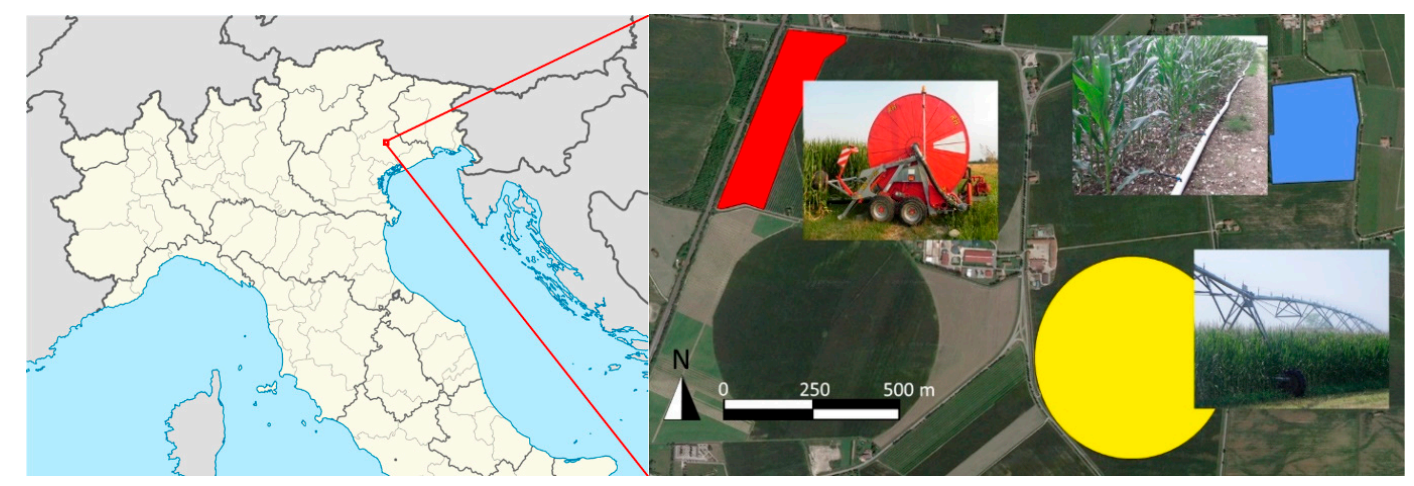

Figure 1. Illustration of the study area on the northeast of Italy (left), and the zoomed image with the three fields with the three irrigation systems identified with different colors (right): center pivot in yellow, micro irrigation in blue, and the hose-reel sprinkler machine in red.

Soil texture is silty-clay-loam textured (sand $12 \%$, loam $61 \%$, clay $27 \%$ ). The area is characterized by the presence of $9 \%$ of gravel. The soil is sub-alkaline ( $\mathrm{pH} 7.4$ ) with a $2.2 \%$ organic matter and $1.3 \%$ of organic carbon. Soil nitrogen is about $1.37 \mathrm{~g} \mathrm{~kg}^{-1}$; usable phosphorous $\left(\mathrm{P}_{2} \mathrm{O}_{5}\right)$ is $55 \mathrm{ppm}$ and potassium is $275 \mathrm{ppm}$ of $\mathrm{K}_{2} \mathrm{O}$. 
Agronomical management has foreseen a $35 \mathrm{~cm}$ deep ploughing in autumn, after a fertilization with $50 \mathrm{t} \mathrm{ha}^{-1}$ of manure from biogas digestion. Prior to the seedbed preparation, a fertilization with $250 \mathrm{~kg} \mathrm{ha}^{-1}$ of potassium chloride $(\mathrm{KCl})$ and $200 \mathrm{~kg} \mathrm{ha}^{-1}$ of calcium perphosphate $\mathrm{Ca}_{3}\left(\mathrm{PO}_{4}\right)_{2}(\mathrm{P} 46 \%)$ was applied in the fields. Maize was sown on the 20 of March in the pivot plot and on the 1 of April in the other plots at 7-8 plants $\mathrm{m}^{-2}$ density. A second fertilization with $500 \mathrm{~kg} \mathrm{ha}^{-1}$ of urea $\mathrm{N} 46 \%$ (230 $\mathrm{kg} \mathrm{ha}^{-1}$ of nitrogen) was applied during the maize growing season in both fields under sprinkler irrigation. In the microirrigation plot, on the other hand, a fertigation with urea was done five times during the early growing season. Maize was harvested on the 1 of September and maize yield was recorded to 11.5 tons ha ${ }^{-1}$ under the drip irrigation system, and to 10.3 and 9.7 tons ha ${ }^{-1}$ under center pivot and hose-reel systems, respectively, while the non-irrigated test performed 4.6 tons ha ${ }^{-1}$.

\subsection{Irrigation}

The irrigation timing was scheduled according to the Irrigation Board calendar compensating the evapotranspiration before water stress occurred. The irrigation season lasted from mid-May to mid-August. Rainfall and temperature data were recorded by a local weather station located in proximity of the farm. The non-irrigated test was located on each plot and kept willingly without water application for a total surface of 0.5 ha.

The three irrigation systems included two sprinklers and a microirrigation system (Figure 1). The sprinkler irrigation systems were a center pivot system and a hose-reel sprinkler. The microirrigation system was a drip line system located in an area of 10 ha. Water was firstly supplied from an irrigation channel, then pumped at a pressure of 1.5 bar by an electro pump of $37 \mathrm{~kW}$ and filtered by three automatic 120 mesh filters. The main line combined a $101.6 \mathrm{~mm}$ line that lay flat and a drip line with $22 \mathrm{~mm}$ of diameter. The drip line was characterized by drippers with a nominal flow rate $1.05 \mathrm{~L} \mathrm{~h}^{-1}$ at 0.8 bar pressure (water applied was $1.4 \mathrm{~mm} \mathrm{~h}^{-1}$ ) and spaced $0.5 \mathrm{~m}$ each other. The drip line was positioned $1.5 \mathrm{~m}$ apart or every two planting rows. The irrigation season counted 12 irrigations for a total of $232 \mathrm{~mm}$ of water volume.

The center pivot system was settled on an area of 40 ha. The pivot was $325 \mathrm{~m}$ long with a terminal section of 25 meters, with the sprinklers positioned every 3 meters. The pressure was 2.2 bar, with a flow rate of $47 \mathrm{~L} \mathrm{~s}^{-1}$. Water was pumped from the irrigation channel with an electro pump of $50 \mathrm{~kW}$ power. The irrigation volume was $25 \mathrm{~mm}$ each irrigation for a total of 10 irrigations and a cumulative irrigation volume of $240 \mathrm{~mm}$ (the last irrigation was $15 \mathrm{~mm}$ ).

The hose-reel machine was settled in 10 ha. Water was pumped from the irrigation channel with a three-impeller motor pump with a $176 \mathrm{~kW}$ diesel engine. The pump pressure was $10 \mathrm{bar}$. The sprinkler gun had a flow rate of $35 \mathrm{~L} \mathrm{~s}^{-1}$ at 6-6.5 bar and about $70 \mathrm{~m}$ of radius of throw. Four irrigations were applied with a total irrigation volume of $200 \mathrm{~mm}$ during the whole irrigation season.

\subsection{Water-Based Indicators}

The environmental performance of the three irrigation systems was calculated applying the indicators of crop water use efficiency (WUE), the irrigation water use efficiency (IWUE) under the irrigation system, and the relative irrigation supply (RIS) indicator, while the impact on water resources was computed using the water footprint [25]. In order to calculate all those indicators of environmental performance, the crop water requirements were previously assessed. The adjusted crop evapotranspiration $\left(E T_{c \text { adj }}\right)$ was assessed on a daily basis according to FAO [26], multiplying the crop coefficient $\left(\mathrm{k}_{\mathrm{c}}\right)$ by $E T_{0}$ and by a water stress coefficient $\left(\mathrm{k}_{\mathrm{s}}\right)$ if a water deficit happened:

$$
E T_{c a d j}=E T_{0} \times k_{c} \times k_{s}
$$

The term "efficiency" can be associated with irrigation systems or can refer to water-use in a broader sense [9]. In this study, the indicator of water use efficiency (WUE) was calculated as the ratio 
between the yield biomass and the actual crop evapotranspiration in $\mathrm{kg} \mathrm{m}^{-3}$ [27] for each irrigation system (i):

$$
W U E_{i}=\frac{B_{a, i}}{E T_{c a d j, i}}
$$

where the actual maize biomass $\left(B_{a}\right)$ under a certain irrigation system $i$ or the biomass produced on the non-irrigated test $\left(B_{\text {test }}\right)$ is related to the adjusted crop evapotranspiration $\left(E T_{\mathcal{c} \text { adj }}\right)$ for irrigated and the non-irrigated maize [28]. In addition, the irrigation water use efficiency (IWUE) was assessed. This indicator evaluates the marginal productivity per cubic meter of water provided by the irrigation. The IWUE $\left(\mathrm{kg} \mathrm{m}^{-3}\right)$ was calculated as following [29]:

$$
\operatorname{IWUE}_{i}=\frac{\left(Y_{a}-Y_{\text {test }}\right)}{I_{r}}
$$

where $Y_{a}\left(\mathrm{~kg} \mathrm{ha}^{-1}\right)$ is the actual grain yield under irrigation, $Y_{\text {test }}\left(\mathrm{kg} \mathrm{ha}^{-1}\right)$ is the non-irrigated yield of the test in the field, and $\mathrm{I}_{\mathrm{r}}\left(\mathrm{m}^{3} \mathrm{ha}^{-1}\right)$ is the irrigation volume applied. IWUE corresponds to the increased production (in dry matter) in comparison to the non-irrigated sample yield in terms of the volume of water used for irrigation. Irrigation is one of the most important factors for increasing crop yield. In order to inform how the management of the irrigation systems during growing period matched the water requirements, the relative irrigation supply (RIS) indicator was assessed [30]:

$$
R I S_{i}=\sum_{u g=1}^{n} \frac{I_{r}}{10 \cdot\left(E T_{\text {cadj }}-P_{e f f}\right)}
$$

Basically, RIS evaluates if irrigation under an irrigation system $i$ matches with the irrigation water deficit relating the ratio of irrigation water volumes over the difference between $\mathrm{ET}_{\mathrm{c}}$ adj and the effective rainfall $\left(\mathrm{P}_{\mathrm{eff}}\right)$. The RIS indicator shows the irrigation system's performance, which is not merely the irrigation efficiency, but it indicates if supply meets the water requirement [31]. RIS values less than 1 indicate a deficit of water application, while larger values indicate a surplus.

In addition to the indicators of efficiency, the impact on water resource was calculated. The water footprint (WF) indicator measures the impact on water consumption in relation to the surface or the yield [32]. The study performed the WF by calculating the water consumption as the green water, which is the rainwater used by maize trough evapotranspiration [33,34], and the blue water, which is the irrigation volume applied to the plants [35]. The green and blue water are different crop water use over the crop growing season, which are calculated for each irrigation system $i$ by the following [36-38]:

$$
\begin{gathered}
C W U_{\text {green }, i}=\sum_{d=1}^{l g p} E T_{c a d j, i} \\
C W U_{\text {blue }, i}=I_{r} \cdot I_{e}
\end{gathered}
$$

The green crop water use $\left(\mathrm{CWU}_{\text {green,i }}\right)$ represents the total rainwater evapotranspired from the planting day (day 1 ) to the day of harvest (lgp, length of growing period). The blue crop water use $\left(\mathrm{CWU}_{\text {blue, }}\right)$ represents the total irrigation water evapotranspired from the crop. The blue crop water use $\left(\mathrm{CWU}_{\text {blue }}\right)$ estimated from Equation (6) considers the irrigation efficiency $\left(\mathrm{I}_{\mathrm{e}}\right)$, which depends on the type of irrigation system used by the farmer: micro or drip irrigation is the most efficient system with a 0.9 coefficient, and sprinkler irrigation (center pivot and hose-reel system) with a 0.7 coefficient [39]. The WF is then calculated as the ratio between the CWU and the yield in terms of $\mathrm{m}^{3}$ ton $^{-1}$ of dry matter or the surface in terms of $\mathrm{m}^{3} \mathrm{ha}^{-1}$ :

$$
\text { WFgreen }_{i}=\frac{C W U_{\text {green }, i}}{Y} \text { or } \frac{C W U_{\text {green }, i}}{\text { Surface }}
$$




$$
\text { WFblue }_{i}=\frac{\mathrm{CWU}_{\text {blue }, i}}{Y} \text { or } \frac{\mathrm{CWU}_{\text {blue }, i}}{\text { Surface }}
$$

\subsection{Biomass and Yield Analysis}

The analysis of maize productivity concerns the field measurements of plant biomass and harvesting mass (yield). The crop growth was determined by the measure of the maize biomass in a two-step survey. The surveys collected maize plants for one square meter in six points of the field. The first biomass survey was done on the 22 of June during the stem elongation and pre-flowering phase, and the second was done on the 28 of July during the full ripening stage of maize grain. The surveys were done for all the fields, and both in the irrigated and in the non-irrigated areas. The aerial biomass was collected, then dried in an oven at $105^{\circ} \mathrm{C}$ for 36 hours, and finally weighed. A statistical analysis was implemented to observe the repeatability of the survey using the standard deviation from the mean of samples. The biomass was used to analyze different indicators related to the crop growing rate and productivity. The crop growth rate (CGR) is the absolute amount of biomass that increases in a certain period, and it was assessed by the equation [40]:

$$
C G R_{i}=\frac{\text { Biomass }_{t 2}-\text { Biomass }_{t 1}}{\text { time }}
$$

where the mass increase $\left(\mathrm{g} \mathrm{day}^{-1}\right)$ is calculated as the difference of the biomass measured at the second survey $\left(\right.$ Biomass $_{t 2}$ ) minus the biomass measured at the first survey $\left(\right.$ Biomass $_{t 1}$ ) by the interval time (days). The biomass measured for the CGR in Equation (9) considers both the total biomass in a first step and the grain production as the ear growing rate. Furthermore, an additional indicator of crop increase biomass is the relative growing rate $(R G R)$, which is the efficiency of growth with respect to mass [40,41]:

$$
R G R_{i}=\frac{\ln _{\text {Biomass }(t 2)}-\ln _{\text {Biomass }(t 1)}}{\text { time }}
$$

The yield data collection was implemented with a field survey on the 28th of August collecting grain samples (ears) in 8 points corresponding to $1 \mathrm{~m}^{2}$ with a replication both on the irrigated and non-irrigated area and during harvesting on the 2nd of September, with a harvester machine recording the yield. The yield performance was analyzed through the index of crop productivity in terms of tons $\mathrm{ha}^{-1}$ of dry matter. Then, the harvest index (HI) was assessed, computing the ratio between the yield and the total biomass collected during the hard dough phase:

$$
H I=\frac{\text { Corn mass }}{\text { Total biomass }}
$$

An additional indicator useful to analyze the crop response to yield is the crop yield response factor to water $(k y)$, which is the ratio between the relative evapotranspiration decrement and the relative yield decrement [42]. The coefficient is useful to analyze how crop can be tolerant to water stress according to different irrigation treatments $i$. The yield response factor was assessed according to the following [43]:

$$
k_{y, i}=\frac{\frac{\left(E T_{i r}-E T_{\text {test }}\right)}{E T_{i r}}}{\frac{\left(Y_{a}-Y_{\text {test }}\right)}{Y a}}
$$

where the $E T_{\text {ir }}(\mathrm{mm})$ is the adjusted crop evapotranspiration within irrigation, and $E T_{\text {test }}(\mathrm{mm})$ is the adjusted crop evapotranspiration of the non-irrigated test. Accordingly, $Y_{a}$ is the crop yield within irrigation, and $Y_{\text {test }}$ is the yield of the non-irrigated test. In a second step, $k y$ was calculated substituting the yield with the CGR to implement a further analysis of the yield response factor. 


\subsection{Economic Balance and Related Indexes of Performance}

The comparison of the economic benefit of irrigation between the three-irrigation systems concerned the analysis of the gross marketable output and the costs. The gross marketable output was performed multiplying the yield (at $14 \%$ humidity) by the corn price on trademark established to $172 €$ $\operatorname{ton}^{-1}$. The corn price referred to the price of the Bologna trademark on a national hybrid corn during the 2015 season. The net income was expressed as the gross income minus the irrigation costs (fixed and variable). Table 1 lists the total gross income, the inventory of expenditures (total irrigation costs), and the net income for the three irrigation systems.

Table 1. Total gross income, costs and net income for the three different irrigation systems. All the items are expressed in $€ \mathrm{ha}^{-1}$.

\begin{tabular}{ccccc}
\hline & Center Pivot System & Drip Irrigation & Hose-reel System & TEST \\
\hline Total gross income & 2054 & 2300 & 1949 & 917 \\
Amortization value & 131 & 62 & 111 & - \\
Labor and maintenance & 30 & 125 & 75 & - \\
Energy & 99 & 104 & 171 & - \\
Cost for drip line & - & 320 & - & - \\
Total Irrigation costs & 260 & 610 & 357 & - \\
Net income & 1794 & 1690 & 1592 & 917 \\
\hline
\end{tabular}

Costs were divided into costs for labor and maintenance, costs for energy, costs for purchasing the equipment, and costs of linear depreciation (amortization). The cost of labor was $15 € \mathrm{~h}^{-1}$, which was the average among permanent and temporary jobs. It considered energetic costs for gasoline $\left(0.65 € \mathrm{~L}^{-1}\right)$ and electricity $\left(0.18 € \mathrm{kWh}^{-1}\right)$ and the price of new machines for the amortization value (higher cost of investment for sprinkler systems) depreciated over their obsolescence time period (10, 15 , and 20 years for drip, hose-reel, and center pivot, respectively). The water price was intentionally not mentioned, because it was considered negligible, since it refers to merely the service cost of water supply by the water board, which is fixed, not volumetric, and computed based on the benefit of growing on irrigated or non-irrigated land.

The economic sustainability analysis considered the indicator of "water productivity" $\left(€ \mathrm{~m}^{-3}\right)$, that is, the ratio between the difference of the net income between the irrigated (Net income ${ }_{i r}$ ) and non-irrigated maize (Net income $e_{t e s t}$ ) and the volume of water used for irrigation:

$$
\text { Water productivity }=\frac{\text { Net income }_{i r}\left(€ \text { ha }^{-1}\right)-\text { Net income }_{\text {test }}\left(€ \text { ha }^{-1}\right)}{\mathrm{I}_{r}\left(\mathrm{~m}^{3} \mathrm{ha}^{-1}\right)}
$$

The water productivity highlighted the positive expected return of irrigation from an economic point of view. The volumetric impact on water resource is given by the ratio of the WF blue or green $\left(\mathrm{m}^{3} \mathrm{ha}^{-1}\right)$ and the marginal economic benefit from irrigation $\left(€ \mathrm{ha}^{-1}\right)$ :

$$
\begin{aligned}
& \text { economic WFgreen }=\frac{\mathrm{WF}_{\text {green }}\left(\mathrm{m}^{3} \text { ha }^{-1}\right)}{\text { Net income }_{\text {ir }}\left(€ \mathrm{ha}^{-1}\right)-\text { Net income }_{\text {test }}\left(€ \text { ha }^{-1}\right)} \\
& \text { economic WFblue }=\frac{\operatorname{CWU}_{\text {blue }}\left(\mathrm{m}^{3} \text { ha }^{-1}\right)}{\text { Net income }_{\text {ir }}\left(€ \text { ha }^{-1}\right)-\text { Net income }_{\text {test }}\left(€ \text { ha }^{-1}\right)}
\end{aligned}
$$

The blue and green WF have a different cost of opportunity and they need to be compared with the marginal net income for a full understanding of their economic performance. 


\subsection{Energetic Balance and Related Indexes}

The irrigation systems were compared in terms of their energetic consumption and greenhouse gas (GHG) emissions. The energetic analysis considered the type of energy used for pumping water and irrigation itself (Table 2). The energy consumption referred to a unit of irrigated surface.

Table 2. Inventory list of annual energy consumption and costs for the three different irrigation systems considered per hectare.

\begin{tabular}{ccccc}
\hline Inventory List & Metric & Drip Irrigation & Center Pivot & Hose-Reel \\
\hline Number of irrigations & $\mathrm{n}^{\circ}$ & 12 & 10 & 5 \\
Electricity consumption & ${\left.\mathrm{kWh}{ }^{*}\right)}^{\text {single irrigation per hectare }}$ & 48 & 55 & 52.5 \\
Energy cost & $€ \mathrm{ha}^{-1}$ & 104 & 99 & 171 \\
Electricity price & $€ \mathrm{kWh}^{-1}\left(^{* *}\right)$ & 0.18 & 0.18 & 0.65 \\
\hline
\end{tabular}

${ }^{*}$ Diesel $(\mathrm{L})$ in case of hose-reel system. ${ }^{* *}$ Diesel price $\left(€ \mathrm{~L}^{-1}\right)$ in case of hose-reel system.

Energy consumption is the product of the electricity or the diesel consumed per hectare by the number of irrigations. Thereby, the conversion factor was used for electricity $(1 \mathrm{kWh}=3.6 \mathrm{MJ})$ and diesel $(1 \mathrm{~L}=42.7 \mathrm{MJ})$. The energetic costs were assessed as the product of the energy consumption and the unit cost [44]. The energy-related indicators are described by the impact of energy consumption per unit of irrigation water consumed:

$$
\text { Energetic Footprint }=\frac{\mathrm{CWU}_{\text {blue }}}{\text { Energy consumption }}
$$

Similarly, the energetic cost footprint is calculated as followed:

$$
\text { Energetic Cost Footprint }=\frac{\mathrm{I}_{r}}{\text { Energy cost }}
$$

The energetic performance is evaluated as the ratio between the energy consumption and the GHG emission with the blue water consumption [45]:

$$
\text { Energetic Performance }=\frac{\text { Energy content }\left(\mathrm{MJ} \mathrm{ha}^{-1}\right) / \mathrm{GHG}\left(\mathrm{kg} \mathrm{CO}_{2-\mathrm{eq} \mathrm{ha}}{ }^{-1}\right)}{\mathrm{CWU}_{\text {blue }}\left(\mathrm{m}^{3} \mathrm{ha}^{-1}\right)}
$$

The energy content is the energetic nutritional content in maize production, where $1 \mathrm{~kg}$ of maize contains $14.75 \mathrm{MJ}$ [46]. The GHG emissions were implemented using the characterization factor of diesel ( $1 \mathrm{~L}$ diesel corresponds to $0.544 \mathrm{~kg} \mathrm{CO}_{2-\mathrm{eq}}$ ) and electricity ( $1 \mathrm{kWh}$ electricity medium voltage at Italian level corresponds to $0.534 \mathrm{~kg} \mathrm{CO}_{2-\mathrm{eq}}$ ) for carbon footprint provided from the Ecoinvent 3.3 database (Ecoinvent, Zurich, Switzerland).

\section{Results and Discussion}

\subsection{Water Based Indicators}

The crop season was characterized by $300 \mathrm{~mm}$ of rainfall. Maize had a different evapotranspiration according to the plant vigor under the different irrigation systems plots. The cumulative water supply from rainfall and irrigation was $534 \mathrm{~mm}$ for drip irrigation, $542 \mathrm{~mm}$ for the center pivot system, and $502 \mathrm{~mm}$ for the hose-reel system (Figure 2). The $\mathrm{ET}_{\mathrm{c} \text { adj }}$ of maize for the entire season was $560 \mathrm{~mm}$ under the drip irrigation, $586 \mathrm{~mm}$ under the center pivot, and $524 \mathrm{~mm}$ under the hose-reel system. 


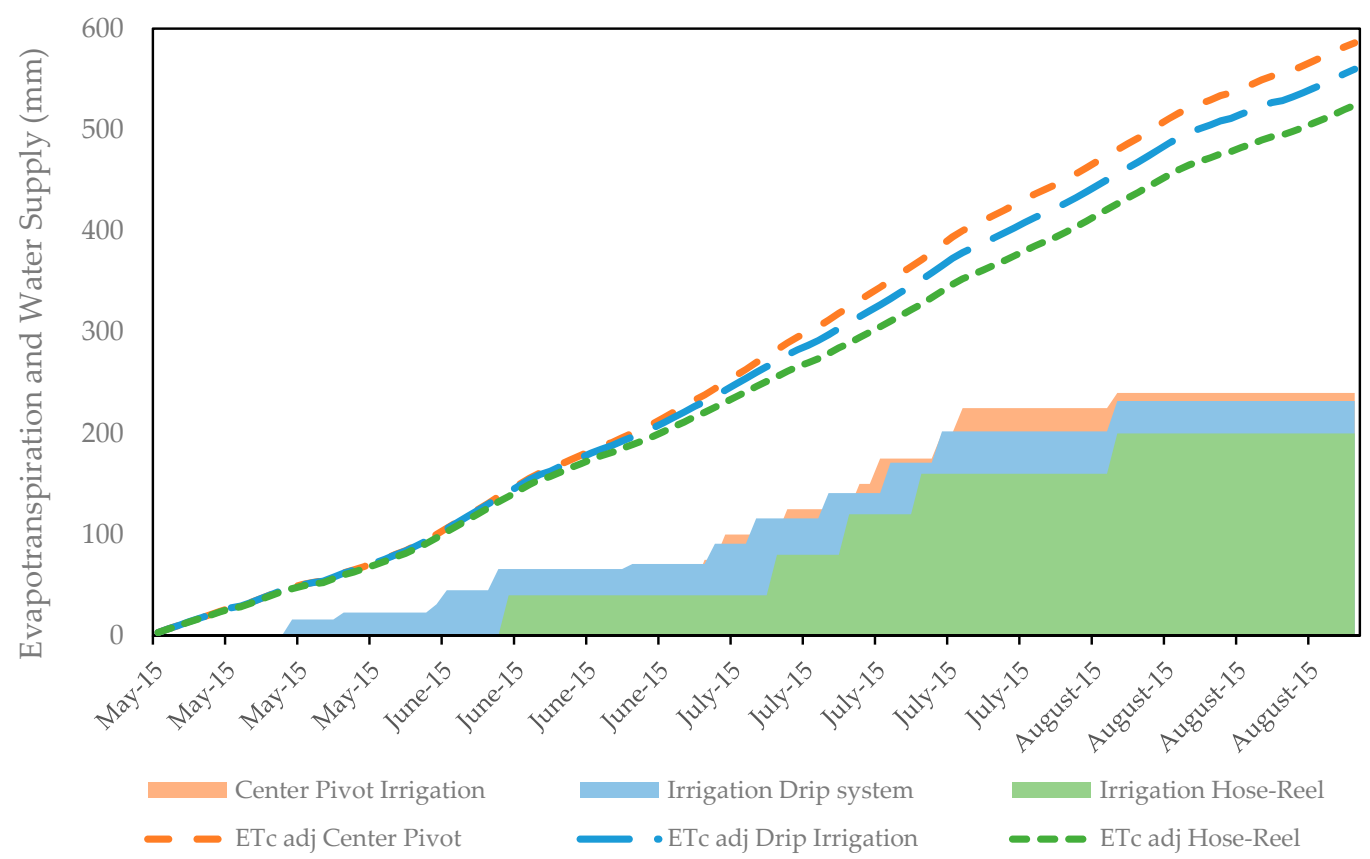

Figure 2. Cumulative water supplied from irrigation and crop evapotranspiration $\left(\mathrm{ET}_{\mathrm{c} \text { adj }}\right)$ over the growing season for each irrigation system.

During the growing season, the maize under the center pivot gained a greater water supply than all the other irrigation systems. The water supplied with irrigation and rainfall met the crop water requirement all the time. In drip irrigation, the irrigation met the crop water requirement with no water stress, while in the maize plot under the hose-reel system, the maize suffered from water stress only in the last period during the phase of corn ripening (Figure 2).

The WUE shows the efficiency of water consumption and biomass production, which is related with the crop growing stage (Table 3). The WUE was determined in two different periods of the growing season during which time there were slight differences between irrigated and non-irrigated tests visible when looking on the WUE from the 22 of June to the 28 of June (Table 3). It is curious to note how the non-irrigated test had a higher WUE $\left(1.317 \mathrm{~kg} \mathrm{~m}^{-3}\right)$ than the hose-reel system $\left(0.972 \mathrm{~kg} \mathrm{~m}^{-3}\right)$, although the lower evapotranspiration and biomass production of the test. This might be explained by the fact that the non-irrigated test benefitted from the rainfall water supply at the begin of the season and suffered later from the water stress, while the difference with a lower WUE within the hose-reel system might be due to other factors of loss beside irrigation (diseases). The difference in WUE started with the late season, where drip irrigation $\left(1.875 \mathrm{~kg} \mathrm{~m}^{-3}\right)$ and center pivot systems $\left(2.04 \mathrm{~kg} \mathrm{~m}^{-3}\right)$ reached higher values.

Table 3. Comparison of water use efficiency (WUE), irrigation water use efficiency (IWUE), and relative irrigation supply (RIS) under different irrigation systems. The dates of WUE are reported where the non-irrigated test is included.

\begin{tabular}{ccccc}
\hline Irrigation Plot & $\begin{array}{c}\text { WUE 22-June } \\
\mathbf{~ k g ~ m ~}^{\mathbf{3}}\end{array}$ & $\begin{array}{c}\text { WUE 28-July } \\
\mathbf{~ k g ~ m ~}^{\mathbf{- 3}}\end{array}$ & $\begin{array}{c}\text { IWUE } \\
\mathbf{k g ~ m}^{\mathbf{3}}\end{array}$ & RIS \\
\hline Drip irrigation & 1.251 & 1.875 & 2.981 & 0.79 \\
Center Pivot & 1.349 & 2.040 & 2.370 & 0.75 \\
Hose-reel system & 0.972 & 1.541 & 2.580 & 0.78 \\
Non-irrigated test & 1.319 & 1.627 & & \\
\hline
\end{tabular}

In addition, the IWUE was higher in drip irrigation $\left(2.981 \mathrm{~kg} \mathrm{~m}^{-3}\right)$ and hose-reel irrigation systems $\left(2.58 \mathrm{~kg} \mathrm{~m}^{-3}\right)$, which meant that the productivity obtained from a unit of water supplied with the 
practice of irrigation provided a better response than with the center pivot $\left(2.37 \mathrm{~kg} \mathrm{~m}^{-3}\right)$. This was true because the hose-reel system furnished a lower amount of water with the irrigation, and drip irrigation gained a better performance combining irrigation volume and crop yield. The RIS was very similar over the three irrigation systems and it stood between 0.75 for the center pivot and 0.79 for drip irrigation. In other words, drip irrigation expressed better the efficiency on supplying water compared to the other irrigation systems because of its superior management.

The WUE and the IWUE are two indicators that have similar metric, but they are conceptually different. According to the Sustainable Development Goals, a sustainable irrigation practice can produce more food with less water. In this sense, drip irrigation is the one that results in a greater ear production to the detriment of a lower total biomass production per $\mathrm{m}^{3}$.

In addition, the impact on the water resource from water consumption is expressed as the blue and green water footprint. Figure 3 expresses blue WF and green WF as the water consumed over the edible biomass produced. The blue WF was lower under the hose-reel system with $144 \mathrm{~m}^{3}$ ton $^{-1}$. The reason is due to the lower irrigation volume applied, while drip irrigation and center pivot presented a blue WF of $182 \mathrm{~m}^{3}$ ton $^{-1}$ and $164 \mathrm{~m}^{3}$ ton $^{-1}$, respectively. In addition, the green WF under the hose-reel system gained the higher value of $274 \mathrm{~m}^{3}$ ton $^{-1}$, and only $232 \mathrm{~m}^{3}$ ton $^{-1}$ and $260 \mathrm{~m}^{3}$ ton $^{-1}$ for drip irrigation and center pivot, respectively (Figure 3). In addition, the green WF of the non-irrigated test had the greatest value of $583 \mathrm{~m}^{3}$ ton $^{-1}$.

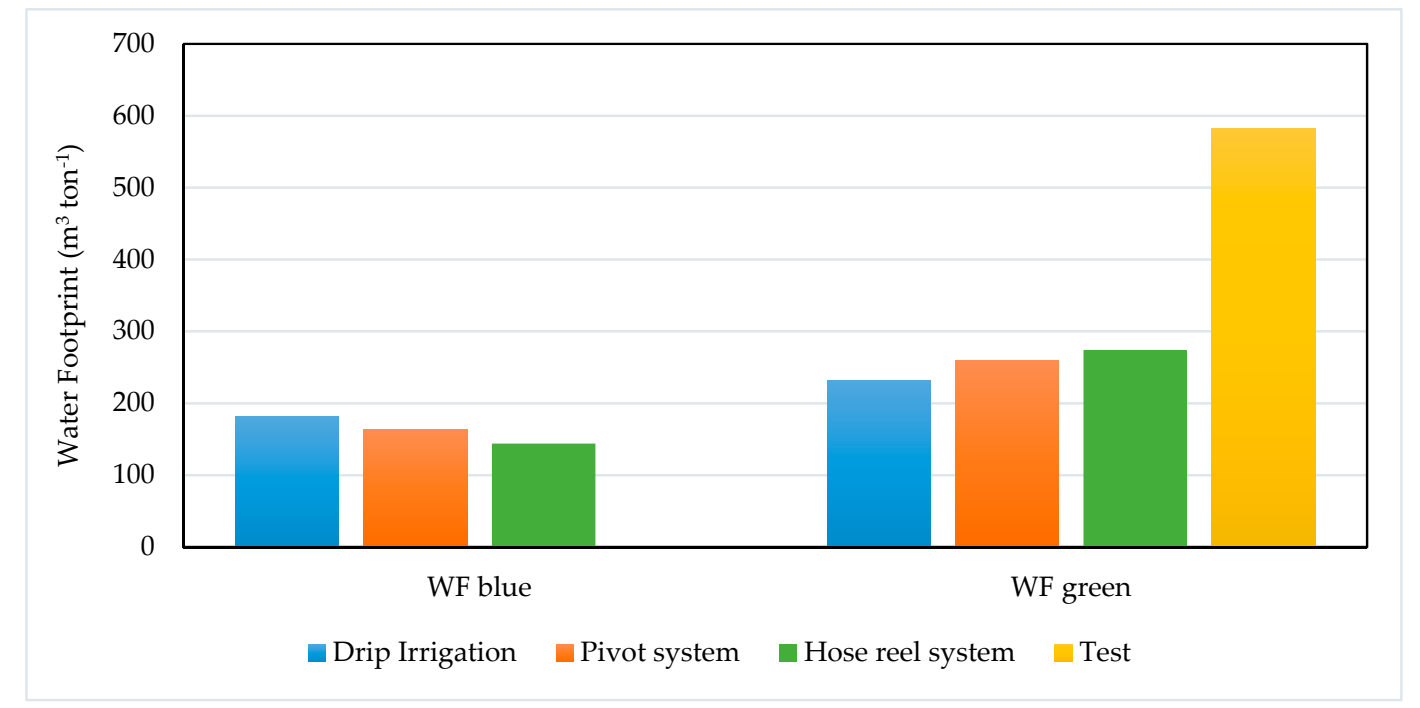

Figure 3. Water footprint (WF) blue and green of each irrigation system in terms of $^{3}$ ton $^{-1}$. For Water Footprint (WF) green, the non-irrigated test was included.

\subsection{Indicator for Biomass and Yield Evaluation}

The crop yield registered during the harvesting stage was higher in the center pivot with 11.5 tons $\mathrm{ha}^{-1}$, followed by maize under drip irrigation system with 10.3 tons ha ${ }^{-1}$ and hose-reel with 9.7 tons $\mathrm{ha}^{-1}$. The biomass was measured in two phenological stages (BBCH-scale [47]): end of stem elongation (BBCH 39) and ripening-early dough ( $\mathrm{BBCH} 83)$. The HI measures the relation between the harvest product and the biomass produced under the related irrigation system, which was higher (0.533) for the hose-reel irrigation machine (Table 4). Center pivot shows a relatively low HI (0.478) due to the higher biomass production, while the rain-fed (non-irrigated test) has the lowest $\mathrm{HI}$ in relation with the lowest yield production (0.416). Table 4 reports both the CGR that shows the difference in maize vigor under the different irrigation systems, and the RGR that determines the mass productivity and the efficiency of growth from the end stage of stem elongation to the early dough of corn kernels (Table 4). 
Table 4. Indicators of performance of biomass and harvest production such as the harvest index (HI), crop growth rate (CGR), and relative growth rate (RGR) are shown for drip, center pivot, and hose-reel irrigation systems.

\begin{tabular}{|c|c|c|c|c|c|}
\hline $\begin{array}{l}\text { Irrigation } \\
\text { System }\end{array}$ & $\begin{array}{l}\text { HI at } \\
\text { Hard Dough Phase } \\
\mathrm{kg}_{\text {harvest }} \mathrm{kg}_{\text {biomass }}{ }^{-1}\end{array}$ & $\begin{array}{l}\text { CGR Maize } \\
\text { Biomass } \\
\text { g day }^{-1}\end{array}$ & $\begin{array}{l}\text { CGR Maize } \\
\text { Ear } \\
\text { g day }{ }^{-1}\end{array}$ & $\begin{array}{l}\text { RGR Maize } \\
\text { Biomass } \\
\text { g g }^{-1} \text { day }^{-1}\end{array}$ & $\begin{array}{l}\text { RGR Maize } \\
\text { Ear } \\
\text { g g }^{-1} \text { day }^{-1}\end{array}$ \\
\hline Drip irrigation & 0.521 & 13.5 & 21.5 & 0.031 & 0.031 \\
\hline Center pivot & 0.478 & 15.9 & 17.5 & 0.033 & 0.026 \\
\hline Hose-reel & 0.533 & 10.4 & 18.9 & 0.032 & 0.033 \\
\hline Test & 0.416 & 6.4 & 7.3 & 0.019 & 0.024 \\
\hline
\end{tabular}

The CGR was different between irrigation systems if we consider the total biomass, where the center pivot had the greater value of $15.9 \mathrm{~g} \mathrm{day}^{-1}$ (Table 4). Moreover, looking to the CGR for the edible part of corn, the drip irrigation system had the greater value $\left(21.5 \mathrm{~g} \mathrm{day}^{-1}\right)$. The maize growing speed was described by the RGR indicator $\left(\mathrm{g} \mathrm{g}^{-1} \mathrm{day}^{-1}\right)$, which was higher under the center pivot in terms of total biomass $\left(0.033 \mathrm{~g} \mathrm{~g}^{-1} \mathrm{day}^{-1}\right)$, and greater under the hose-reel in terms of ear production $(0.033 \mathrm{~g}$ $\mathrm{g}^{-1}$ day $\left.^{-1}\right)$. The RGR under drip irrigation showed that this type of system allows one to reduce water stress and plants can grow at the same rate both for the edible part of the corn ear and for the vegetal part of steam and leaves. A further indicator of biomass productivity and crop performance is the dimensionless crop yield response factor $\left(\mathrm{k}_{\mathrm{y}}\right)$. This indicator helps to understand the contribution of irrigation on crop productivity and the occurrence of a potential water deficit. As seen in Figure 4, different maize conditions under different irrigation management showed also that the yield response factor was greater within the center pivot system due to the higher evapotranspiration in relation to the yield. This is different if the biomass productivity is considered; the $\mathrm{k}_{\mathrm{y}}$ CGR describes a different trend of the crop response on biomass production in relation with irrigation. The hose-reel irrigator machine has the higher value of 0.57 in comparison with the drip irrigation that gains a value of 0.41 . A general definition of $\mathrm{k}_{\mathrm{y}}$ factor defines that the higher the value is, the more sensible is the crop to water deficit. Figure 4 shows how $\mathrm{k}_{\mathrm{y}}$ might change between different irrigation practices looking either to the biomass or to the grains production. In Figure 4, the error bars are added to describe the standard deviation from between the irrigated plots and the rain-fed test.

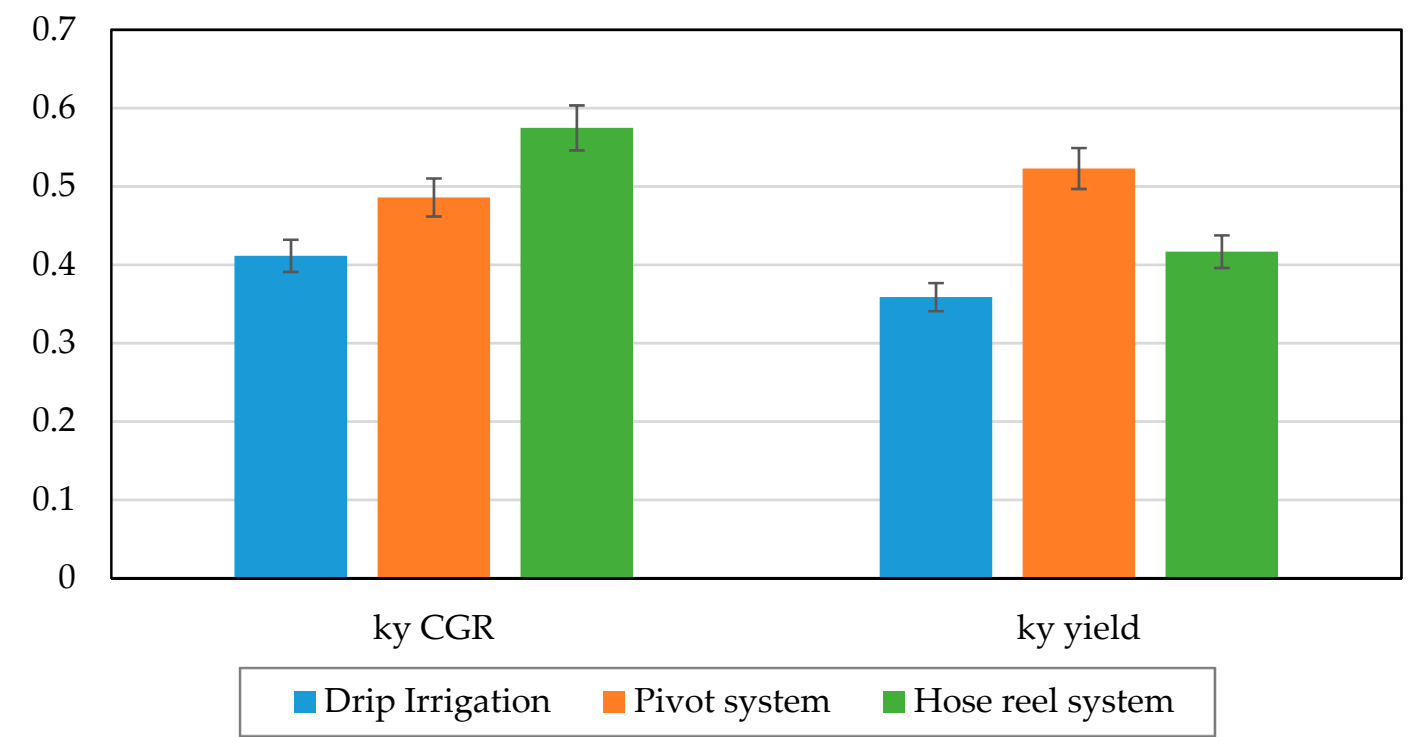

Figure 4. Crop yield response factor ( $\mathrm{k}_{\mathrm{y}}$ yield) of harvesting product and the $\mathrm{k}_{\mathrm{y}}$ from biomass production $\left(\mathrm{k}_{\mathrm{y}}\right.$ crop growth rate (CGR) of maize under different irrigation systems. 


\subsection{Economic Indicators}

The economic aspect of sustainability of irrigation systems deals with the use of the indicator of water productivity and the economic water footprint. The water productivity is the economic benefit of an additional unit of water. Looking to the water productivity, the greater value was observed for center pivot $\left(0.37 € \mathrm{~m}^{-3}\right)$, which presented a higher irrigation volume in relation with a higher net income by $12 \%$ and $8 \%$ than drip irrigation $\left(0.33 € \mathrm{~m}^{-3}\right)$ and hose-reel machine $\left(0.34 € \mathrm{~m}^{-3}\right)$, respectively. Figure 5 shows the relation between the water consumed to produce a unit of income explained by the economic water footprint (WF) of different irrigation systems. In fact, blue and green water use had different opportunity costs. This was especially more evident under the hose-reel system where a lower economic WF blue $\left(2.07 \mathrm{~m}^{3} €^{-1}\right)$ corresponding to a higher economic WF green $\left(3.95 \mathrm{~m}^{3} €^{-1}\right)$. The center pivot machine gained a great water productivity and the lowest impact on water resource with $1.91 \mathrm{~m}^{3} €^{-1}$ and $3.04 \mathrm{~m}^{3} €^{-1}$ for WF blue and WF green, respectively. In this paper, a general consideration was needed when looking to economic indicators, because a small variation in the market price can vary consistently the gross marketable income, and in the meantime could tip the economic balance in favor of one or another irrigation system due to the high weight of this economic component compared to the rest of the balance.

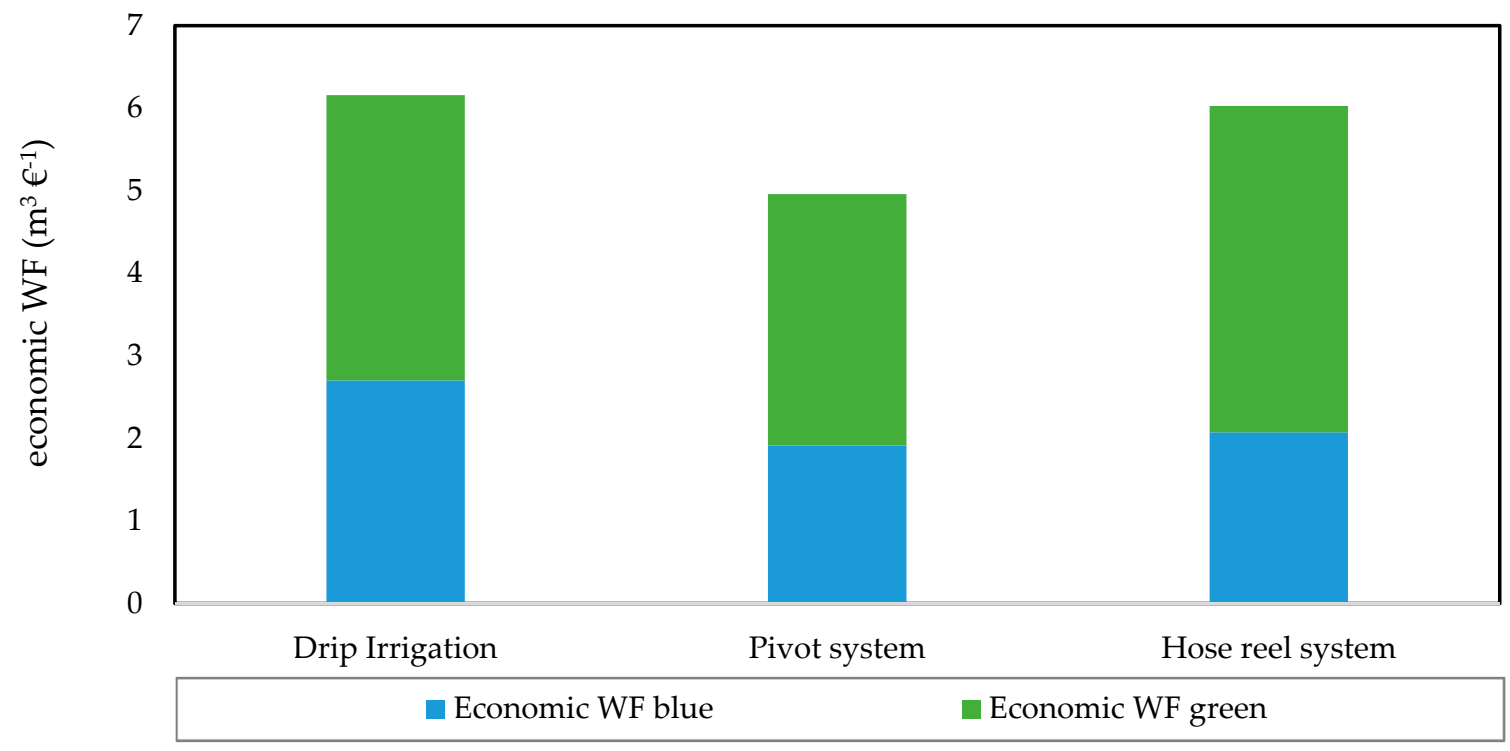

Figure 5. Water productivity and economic water footprint of different irrigation systems.

\subsection{Energetic Indicators}

The energy consumption for irrigation purposes involves GHG emissions related to the electricity and diesel consumption for the engine pumping water. GHG emissions held from drip irrigation correspond to $308 \mathrm{~kg} \mathrm{CO}_{2-\mathrm{eq}} \mathrm{ha}^{-1}$, while they decreased to $26 \mathrm{~kg} \mathrm{CO}_{2-\mathrm{eq}} \mathrm{ha}^{-1}$ if looking to the single irrigation. The total GHG emissions for the center pivot and hose-reel systems were 294 and $143 \mathrm{~kg}$ $\mathrm{CO}_{2-\text { eq }} \mathrm{ha}^{-1}$, respectively. Those values changed when we considered the GHG emissions of the single irrigation of $29.4 \mathrm{~kg} \mathrm{CO}_{2-\mathrm{eq}} \mathrm{ha}^{-1}$ for center pivot and $28.5 \mathrm{~kg} \mathrm{CO}_{2-\mathrm{eq}} \mathrm{ha}^{-1}$ in the case of the hose-reel system (Table 5). The energetic footprint shows the water consumption per unit of energy consumed per irrigation. Drip irrigation gained a greater value $\left(1 \mathrm{~m}^{3} \mathrm{MJ}^{-1}\right)$, while the center pivot consumed $0.85 \mathrm{~m}^{3}$ per MJ consumed, and the hose-reel spent $0.12 \mathrm{~m}^{3} \mathrm{MJ}^{-1}$. The energetic cost footprint is the water consumption supplied with irrigation per unit of energy cost. The center pivot was the more efficient system in terms of water supplied per unit of cost of energy spent $\left(24.2 \mathrm{~m}^{3} €^{-1}\right)$. Drip irrigation and hose-reel systems showed an energetic cost footprint of $22.3 \mathrm{~m}^{3} €^{-1}$ and $11.7 \mathrm{~m}^{3} €^{-1}$, respectively (Table 5). Differently, the energy performances are given from the relation between the ratio of energy content in maize, the GHG emissions, and the blue WF. The hose-reel system showed the greater 
value of energy performance with $0.35 \mathrm{MJ} \mathrm{m}^{3} \mathrm{kgCO}_{2-\mathrm{eq}}{ }^{-1}$. Drip irrigation and center pivot showed a lower value of $0.21 \mathrm{MJ} \mathrm{m}^{3} \mathrm{kgCO}_{2-\mathrm{eq}}{ }^{-1}$ and $0.15 \mathrm{MJ} \mathrm{m}^{3} \mathrm{kgCO}_{2-\mathrm{eq}}{ }^{-1}$, respectively. Energy indicators related to environmental impact for the different irrigation systems studied allowed us to understand energy performance, the environmental impact from the energetic point of view, and in relation to water consumption.

Table 5. Energy indicators of environmental impact for irrigation practice comparing different irrigation systems.

\begin{tabular}{lcccc}
\hline & $\begin{array}{c}\text { Energetic } \\
\text { Footprint } \\
\mathbf{m}^{\mathbf{3}} \mathbf{M J}^{-\mathbf{1}}\end{array}$ & $\begin{array}{c}\text { Energetic Cost } \\
\text { Footprint } \\
\mathbf{m}^{\mathbf{3}} \mathbf{\epsilon}^{-\mathbf{1}}\end{array}$ & $\begin{array}{c}\text { Energy } \\
\text { Performance } \\
\mathbf{M J ~ m}^{\mathbf{3}} \\
\mathbf{k g C O}_{\mathbf{2}-\mathbf{e q}} \mathbf{- 1}\end{array}$ & $\begin{array}{c}\text { GHG Emission } \\
\text { Per Irrigation } \\
\mathbf{k g C O}_{\mathbf{2}-\mathbf{e q}} \mathbf{h a}^{-\mathbf{1}}\end{array}$ \\
\hline Drip irrigation & 1.00 & 22.3 & 0.21 & 26 \\
Center pivot system & 0.85 & 24.2 & 0.15 & 29 \\
Hose-reel system & 0.12 & 11.7 & 0.35 & 29 \\
\hline
\end{tabular}

\section{Conclusions}

This study provides different environmental indicators suited to analyze the sustainability of different irrigation systems. The study includes indicators of water balance, economic balance, and energetic analysis. Those indicators help users to detect the most performant irrigation system from environmental, energetic, and economic points of view. The main results indicate the center pivot system has generally higher performance among the irrigation systems in this case study. In fact, the CGR, RGR, and $\mathrm{k}_{\mathrm{y}}$ gained a better response under the center pivot. At the same time, indicators related to the economic balance showed that the center pivot was the better irrigation system with higher water productivity and lower economic water footprint. Indicators related to water balance generally performed better under drip irrigation. However, the hose-reel system supplied a lower amount of water (lower WF blue), while the center pivot had a better WUE but a worse IWUE. Finally, drip irrigation showed better performance on IWUE and RIS, and with a lower WF green. Looking to the energetic performance, there is no clear picture of the best performant irrigation system. However, drip irrigation gained a higher energetic footprint, while the center pivot had a higher energetic cost footprint, and the hose-reel system showed a better energetic performance. Comparing the overall contribution on the environmental sustainability, the center pivot system combines good performance and presents an overall good solution for irrigation sustainability, especially from an economic point of view.

This study enhances the choice of the most appropriate irrigation system held under maize cropping. Further analysis under different crops must be implemented. In fact, the three systems are not always alternatives. For example, a pivot is not feasible on very small plots or on irregularly shaped plots; drip is not applicable to pasture crops (if crops rotate), while sprinkler systems may be; and hose-reel is inefficient in very windy areas. Investment in irrigation should consider crop succession throughout the year. Moreover, a one-year study was carried out; a sensitive analysis should be implemented to analysis what variable might affect the choice of the users to a suitable sustainable irrigation system. Besides that, the use of the correct irrigation system needs to combine a proper irrigation water management to take advantage of its performance.

Author Contributions: Conceptualization, E.B., F.M. and L.B.; Data curation, E.B. and M.M.; Formal analysis, E.B.; Funding acquisition, F.M.; Investigation, E.B. and M.M.; Methodology, E.B.; Project administration, L.B.; Resources, F.M. and L.B.; Supervision, F.M. and L.B.; Validation, L.B.; Writing-original draft, E.B.; Writing-review and editing, F.M. and L.B.

Funding: The research has been supported by the Ph.D. grant provided by Fondazione Cassa di Risparmio di Padova e Rovigo (CARIPARO).

Conflicts of Interest: The authors declare no conflict of interest. 


\section{References}

1. Rockström, J.; Williams, J.; Daily, G.; Noble, A.; Matthews, N.; Gordon, L.; Wetterstrand, H.; DeClerck, F.; Shah, M.; Steduto, P.; et al. Sustainable intensification of agriculture for human prosperity and global sustainability. Ambio 2017, 46, 4-17. [CrossRef]

2. Chartzoulakis, K.; Bertaki, M. Sustainable Water Management in Agriculture under Climate Change. Agric. Agric. Sci. Procedia 2015, 4, 88-98. [CrossRef]

3. Alcamo, J.; Döll, P.; Henrichs, T.; Kaspar, F.; Lehner, B.; Rösch, T.; Siebert, S. Global estimates of water withdrawals and availability under current and future "business-as-usual" conditions. Hydrol. Sci. J. 2003, 48, 339-348. [CrossRef]

4. Directorate-General for Environment. Ecological Flows in the Implementation of the Water Framework Directive: Guidance Document N³1; European Commission: Bruxelles, Belgium, 2016; ISBN 978-92-79-45758-6.

5. Smakhtin, V.; Revenga, C.; Döll, P. A pilot global assessment of environmental water requirements and scarcity. Water Int. 2004, 29, 307-317. [CrossRef]

6. Sullivan, C. Calculating a Water Poverty Index. World Dev. 2002, 30, 1195-1210. [CrossRef]

7. Rosa, L.; Rulli, M.C.; Davis, K.F.; Chiarelli, D.D.; Passera, C.; D'Odorico, P. Closing the yield gap while ensuring water sustainability. Environ. Res. Lett. 2018, 13, 104002. [CrossRef]

8. D'Odorico, P.; Davis, K.F.; Rosa, L.; Carr, J.A.; Chiarelli, D.; Dell'Angelo, J.; Gephart, J.; MacDonald, G.K.; Seekell, D.A.; Suweis, S.; et al. The Global Food-Energy-Water Nexus. Rev. Geophys. 2018, 56, 456-531. [CrossRef]

9. Unver, O.; Bhaduri, A.; Hoogeveen, J. Water-use efficiency and productivity improvements towards a sustainable pathway for meeting future water demand. Water Secur. 2017, 1, 21-27. [CrossRef]

10. Grafton, R.Q.Q.; William, J.; Perry, C.J.J.; Molle, F.; Ringler, C.; Steduto, P.; Udall, B.; Wheeler, S.A.A.; Wang, Y.; Garrick, D.; et al. The paradox of irrigation efficiency. Science 2018, 361, 748-750. [CrossRef]

11. Falkenmark, M. Society's interaction with the water cycle: A conceptual framework for a more holistic approach. Hydrol. Sci. J. 1997, 42, 451-466. [CrossRef]

12. Tuninetti, M.; Tamea, S.; Dalin, C. Water Debt Indicator Reveals Where Agricultural Water Use Exceeds Sustainable Levels. Water Resour. Res. 2019, 55, 2464-2477. [CrossRef]

13. Borsato, E.; Galindo, A.; Tarolli, P.; Sartori, L.; Marinello, F. Evaluation of the grey water footprint comparing the indirect effects of different agricultural practices. Sustainability 2018, 10, 3992. [CrossRef]

14. Mejía, A.; Hubner, M.N.; Sánchez, E.R.; Doria, M. Water and Sustainability: A Review of Targets, Tools and Regional Cases; UNESCO: Paris, France, 2012; ISBN 9789230010942.

15. Gómez-Limón, J.A.; Riesgo, L. Alternative approaches to the construction of a composite indicator of agricultural sustainability: An application to irrigated agriculture in the Duero basin in Spain. J. Environ. Manag. 2009, 90, 3345-3362. [CrossRef] [PubMed]

16. Bubb, R.; Kaur, S.; Mullainathan, S. Barriers to contracting in village economies: A test for enforcement constraints. Unpublished work, 2016.

17. Pellegrini, E.; Bortolini, L.; Defrancesco, E. Coordination and Participation Boards under the European Water Framework Directive: Different approaches used in some EU countries. Water 2019, 11, 833. [CrossRef]

18. Vanham, D.; Hoekstra, A.Y.; Wada, Y.; Bouraoui, F.; de Roo, A.; Mekonnen, M.M.; van de Bund, W.J.; Batelaan, O.; Pavelic, P.; Bastiaanssen, W.G.M.; et al. Physical water scarcity metrics for monitoring progress towards SDG target 6.4: An evaluation of indicator 6.4.2 "Level of water stress". Sci. Total Environ. 2018, 613-614, 218-232. [CrossRef] [PubMed]

19. Chaves, H.M.L.; Alipaz, S. An integrated indicator based on basin hydrology, environment, life, and policy: The watershed sustainability index. Water Resour. Manag. 2007, 21, 883-895. [CrossRef]

20. Galli, A.; Wiedmann, T.; Ercin, E.; Knoblauch, D.; Ewing, B.; Giljum, S. Integrating Ecological, Carbon and Water footprint into a "footprint Family" of indicators: Definition and role in tracking human pressure on the planet. Ecol. Indic. 2012, 16, 100-112. [CrossRef]

21. Čuček, L.; Klemeš, J.J.; Kravanja, Z. A review of footprint analysis tools for monitoring impacts on sustainability. J. Clean. Prod. 2012, 34, 9-20. [CrossRef]

22. Rennings, K.; Wiggering, H. Steps towards indicators of sustainable development: Linking economic and ecological concepts. Ecol. Econ. 1997, 20, 25-36. [CrossRef] 
23. Galindo, A.; Collado-González, J.; Griñán, I.; Corell, M.; Centeno, A.; Martín-Palomo, M.J.; Girón, I.F.; Rodríguez, P.; Cruz, Z.N.; Memmi, H.; et al. Deficit irrigation and emerging fruit crops as a strategy to save water in Mediterranean semiarid agrosystems. Agric. Water Manag. 2018, 202, 311-324. [CrossRef]

24. Herva, M.; Franco, A.; Carrasco, E.F.; Roca, E. Review of corporate environmental indicators. J. Clean. Prod. 2011, 19, 1687-1699. [CrossRef]

25. Marino, G.; Zaccaria, D.; Snyder, R.L.; Lagos, O.; Lampinen, B.D.; Ferguson, L.; Grattan, S.R.; Little, C.; Shapiro, K.; Maskey, M.L.; et al. Actual Evapotranspiration and Tree Performance of Mature Micro-Irrigated Pistachio Orchards Grown on Saline-Sodic Soils in the San Joaquin Valley of California. Agriculture 2019, 9, 76. [CrossRef]

26. Allen, R.G.; Pereira, L.S.; Raes, D.; Smith, M. Crop Evapotranspiration. In FAO Irrigation and Drainage Paper No. 56; FAO: Rome, Italy, 1998; Volume 56, p. 333. ISBN 92-5-104219-5.

27. Lovelli, S.; Perniola, M.; Ferrara, A.; Di Tommaso, T. Yield response factor to water $\left(\mathrm{K}_{\mathrm{y}}\right)$ and water use efficiency of Carthamus tinctorius L. and Solanum melongena L. Agric. Water Manag. 2007, 92, 73-80. [CrossRef]

28. Steduto, P.; Albrizio, R. Resource use efficiency of field-grown sunflower, sorghum, wheat and chickpea: II. Water use efficiency and comparison with radiation use efficiency. Agric. For. Meteorol. 2005, 130, $269-281$. [CrossRef]

29. Molden, D.; Oweis, T.; Steduto, P.; Bindraban, P.; Hanjra, M.A.; Kijne, J. Improving agricultural water productivity: Between optimism and caution. Agric. Water Manag. 2010, 97, 528-535. [CrossRef]

30. Morillo, J.G.; Díaz, J.A.R.; Camacho, E.; Montesinos, P. Linking water footprint accounting with irrigation management in high value crops. J. Clean. Prod. 2015, 87, 594-602. [CrossRef]

31. Playán, E.; Mateos, L. Modernization and optimization of irrigation systems to increase water productivity. Agric. Water Manag. 2006, 80, 100-116. [CrossRef]

32. Hoekstra, A.Y.; Chapagain, A.K.; Aldaya, M.M.; Mekonnen, M.M. The Water Footprint Assessment Manual; Earthscan: London, UK, 2011; ISBN 9781849712798.

33. Chukalla, A.D.; Krol, M.S.; Hoekstra, A.Y. Green and blue water footprint reduction in irrigated agriculture: Effect of irrigation techniques, irrigation strategies and mulching. Hydrol. Earth Syst. Sci. 2015, 19, 4877-4891. [CrossRef]

34. Mekonnen, M.M.; Hoekstra, A.Y. National water footprint accounts: The green, blue and grey water footprint of production and consumption. In Value of Water Research Report Series No. 50; UNESCO-IHE: Delft, The Netherlands, 2011.

35. Bonamente, E.; Scrucca, F.; Rinaldi, S.; Merico, M.C.; Asdrubali, F.; Lamastra, L. Environmental impact of an Italian wine bottle: Carbon and water footprint assessment. Sci. Total Environ. 2016, 560, 274-283. [CrossRef]

36. Lamastra, L.; Suciu, N.A.; Novelli, E.; Trevisan, M. A new approach to assessing the water footprint of wine: An Italian case study. Sci. Total Environ. 2014, 490, 748-756. [CrossRef] [PubMed]

37. Zhuo, L.; Mekonnen, M.M.; Hoekstra, A.Y. Sensitivity and uncertainty in crop water footprint accounting: A case study for the Yellow River basin. Hydrol. Earth Syst. Sci. 2014, 18, 2219-2234. [CrossRef]

38. Borsato, E.; Giubilato, E.; Zabeo, A.; Lamastra, L.; Criscione, P.; Tarolli, P.; Marinello, F.; Pizzol, L. Comparison of Water-focused Life Cycle Assessment and Water Footprint Assessment: The case of an Italian wine. Sci. Total Environ. 2019, 666, 1220-1231. [CrossRef] [PubMed]

39. Castellanos, M.T.; Cartagena, M.C.; Requejo, M.I.; Arce, A.; Cabello, M.J.; Ribas, F.; Tarquis, A.M. Agronomic concepts in water footprint assessment: A case of study in a fertirrigated melon crop under semiarid conditions. Agric. Water Manag. 2016, 170, 81-90. [CrossRef]

40. Toniolo, L.; Mosca, G.; Sattin, M. Crop physiology aspects of soybean versus maize in north-eastern Italy. Rivista di Agronomia 1985, 19, 251-257.

41. Hunt, R.; Causton, D.R.; Shipley, B.; Askew, A.P. A Modern Tool for Classical Plant Growth Analysis. Ann. Bot. 2002, 90, 484-488. [CrossRef] [PubMed]

42. Haghverdi, A.; Leib, B.; Washington-Allen, R.; Wright, W.; Ghodsi, S.; Grant, T.; Zheng, M.; Vanchiasong, P. Studying Crop Yield Response to Supplemental Irrigation and the Spatial Heterogeneity of Soil Physical Attributes in a Humid Region. Agriculture 2019, 9, 43. [CrossRef]

43. Doorenbos, J.; Pruitt, W.O. Guidelines for predicting crop water requirements. In FAO Irrigation and Drainage Paper 24; FAO: Rome, Italy, 1977.

44. Handa, D.; Frazier, R.; Taghvaeian, S.; Warren, J. The Efficiencies, Environmental Impacts and Economics of Energy Consumption for Groundwater-Based Irrigation in Oklahoma. Agriculture 2019, 9, 27. [CrossRef] 
45. Borsato, E.; Tarolli, P.; Marinello, F. Sustainable patterns of main agricultural products combining different footprint parameters. J. Clean. Prod. 2018, 179, 357-367. [CrossRef]

46. Carnovale, E.; Marletta, L. Tabelle di Composizione Degli Alimenti. Available online: http://nut.entecra.it/ 646/tabelle_di_composizione_degli_alimenti.html (accessed on 28 August 2019).

47. Hess, M.; Barralis, G.; Bleiholder, H.; Buhr, L.; Eggers, T.H.; Hack, H.; Stauss, R. Use of the extended BBCH scale-general for the descriptions of the growth stages of mono; and dicotyledonous weed species. Weed Res. 1997, 37, 433-441. [CrossRef]

(C) 2019 by the authors. Licensee MDPI, Basel, Switzerland. This article is an open access article distributed under the terms and conditions of the Creative Commons Attribution (CC BY) license (http://creativecommons.org/licenses/by/4.0/). 